\title{
PARADIGMA HISTORIS PENDIDIKAN AGAMA AGAR DOKTRIN AGAMA FUNGSIONAL DI ERA MODERN
}

Oleh: Saefur Rochmat

\begin{abstract}
Abstrak:
Paradigma historis pendidikan agama dimaksudkan agar agama itu fungsional dalam kehidupan modern. Untuk itu, agama harus ikut menangani permasalahan pada era modern ini, mengarahkan perkembangan ilmu modern, dan mengadopsi serta mengembangkan ide-ide dan konsep-konsep modern. Umat Islam perlu akrab dengan permasalahan kemodernan seperti negara bangsa, nasionalism, dan demokrasi.

Model pendidikan agama berdasarkan paradigma historis itu menggabungkan pendekatan konvensional pendidikan agama yang bersifat dogmatis-normatif, pendekatan historis, dan pendekatan kontekstual. Model yang perlu dikembangkan berdasarkan pendekatan historis adalah Agama Reformis, dimana agama difungsikan sebagai motor penggerak perubahan, dengan menjadikan agama selalu bersentuhan dengan konsep-konsep modern, namun ia bersifat kritis terhadap pendekatan ideologis-revolusioner, sehingga ia mengembangkan pendekatan reformatifevolusioner.

Pendekatan historis dan kontekstual baik dapat digunakan sebagai metoda dalam penyampaian pendidikan agama agar doktrin agama itu fungsional dalam kehidupan modern. Adakalanya kita tidak dapat menggunakan kedua pendekatan secara bersama-sama dalam menjelaskan suatu materi pelajaran, namun salah satu dari pendekatan itu secara sendiri-sendiri dapat digunakan untuk menjelaskan materi pelajaran agama. Bahkan, baik pendekatan historis maupun kontekstual dapat digunakan pada Standar Kompetensi yang kelihatannya ekslusif dalam pendidikan agama, yaitu Al-Qur'an, Akidah, Akhlak, dan Fiqih. Satu-satunya Standar Kompetensi terkait erat dengan pendekatan historis dan kontestual adalah Tarikh dan Kebudayaan Islam.
\end{abstract}

Kata kunci: teologi, sektor publik, sektor private, pendekatan historis, pendekatan konvensional

\section{PENDAHULUAN}

\section{A. LATAR BELAKANG MASALAH}

Paradigma konvensional pendidikan agama yang menekankan pendekatan doktriner normatif telah gagal menjawab tantangan zaman. Pendekatan ini tidak dapat mengakomodasi ide-ide modern seperti konsep negara, demokrasi, dan nasionalisme. Akibatnya umat Islam mengalami split identity (kepribadian terpecah), dimana kesalehan individual tidak berdampak pada terbentuknya kesalehan pada sektor publik, sehingga kita sering melihat fenomena yang kontradiktif: seorang yang 
melakukan ibadah haji berkali-kali, tetapi mereka melakukan korupsi ketika terjun dalam sektor publik. Fenomena seperti ini yang dinamai sekulerisme sektor publik.

Kalau tidak jeli kita tidak dapat melihat fenomena sekulerisme sektor publik ini, karena kita melihat jumlah tempat ibadah yang semakin bertambah; jama’ah haji dari Indonesia juga terbanyak di dunia; dan berbagai simbol keagamaan semarak dan mencolok dalam kehidupan sehari-hari. Dampak fenomena sekulerisme sektor publik ini sungguh sangat fatal, kita gagal mewujudkan salvation di dunia ini, seperti gap sikaya dan simiskin begitu mencolok. Memang sekulerisme sektor publik di Barat sangat mencolok, tetapi Barat berhasil mewujudkan salvation di dunia ini seperti relatif terjaminnya kesejahteraan, keadilan, dan keamanan. Hal ini sebagai hasil dari proyek sekulerisasi, yaitu adanya pemisahan managemen sektor publik (urusan negara) dan managemen sektor privat (urusan agama) sehingga sektor publik terhindar dari politisasi agama.

Proyek sekulerisasi di Barat dioperasionalkan untuk menjamin tegaknya sistem demokrasi yang setia pada prinsip check and balance, sehingga sektor publik mendukung tumbuh-kembangnya sektor privat agar dapat memerankan diri sebagai pendukung konsep civil society, yang akan melakukan kritik kontruktif terhadap jalannya pemerintahan. Prinsip check and balance inilah yang seringkali dilupakan oleh para pendukung negara bangsa di negara-negara dunia ketiga dan mereka cederung pada salah satu feature sentralisasi demi mempertahankan kekuasaan bagi diri dan kelompoknya. Padahal, negara Barat tidak melakukan sentralisasi secara berlebihan dan negara menjalin kerjasama dengan sektor privat dalam usahanya untuk meningkatkan kesejahteraan. Bahkan di The Uniteted States of America (USA), jumlah pegawai seluruh negara bagian dan negara federal sekaligus lebih sedikit dibandingkan dengan jumlah pegawai di sektor privat. 
Memang proyek sekulerisasi berdampak pada mewabahnya endemi sekulerisme di Barat, terutama di sektor publik. Sedangkan di sektor privat, gejala sekulerisme tidak terjadi. Paling tidak ini berdasarkan survey yang dilakukan oleh lembaga research ICM terhadap kepercayaan agama di era modern, dimana 92\% rakyat USA masih percaya kepada kekuatan adikodrati. Hasil survey yang lebih mencengangkan, di negara yang sudah mengalami proses modernisasi begitu lama itu, 91\% rakyatnya percaya kalau kehidupan akan lebih damai kalau percaya kepada Tuhan (BBC, 2004: 1-3).

Krisis sektor publik di Barat tidak merugikan eksistensi negara bangsa secara individual, tetapi hal itu tidak dapat menjelaskan tata pergaulan dunia yang melibatkan hubungan antar bangsa dan negara, sehingga dari peradaban modern Barat lahir malapetaka dalam sejarah kemanusiaan seperti penjajahan, Perang Dunia I dan II, perang dingin, dan banyak revolusi yang mengingjak-nginjak martabat kemanusiaan dan mengancam nyawa manusia secara langsung.

\section{B. PERUMUSAN MASALAH}

Dari uraian di atas, kita tahu bahwa krisis yang sedang melanda Barat adalah sekulerisme sektor publik. Indonesia pun sedang mengalami krisis sektor publik karena Pendidikan Agama masih menggunakan pendekatan konvensional yang menafsirkan Al-Qur'an secara skriptural. Pengajaran model konvensional ini hanya mengajarkan doktrin-doktrin agama yang bersifat normatif dengan pendekatan deduktif. Metoda konvensional ini perlu dilengkapi dengan pendekatan induktif berdasarkan paradigma historis sebagai konteks bagi diterapkannya doktrin dalam kehidupan sehari-hari. Doktrin-doktrin agama bukan sesuatu yang netral, tetapi sangat tergantung pada sistem yang menjadi acuan. 
Contohnya, konsep keadilan tidak dapat dilepaskan dari konteksnya, karena keadilan bukanlah suatu yang statis. Bila pemerintah memberi subsidi komoditi bensin kepada seluruh rakyat Indonesia, apakah sudah adil? Jawabannya bisa iya bisa tidak, sangat tergantung dari sudut pandang yang dijadikan acuan. Yang jelas, yang menerima subsidi lebih banyak adalah orang kaya yang memiliki kendaraan banyak. Tetapi apakah orang Irian Jaya yang masih memakai koteka diuntungkan dengan kebijakan ini? Mereka tidak mendapatkan apa-apa! Memang keadilan memiliki ciriciri dan karakteristik-karakteristik yang obyektif, namun perlu dijabarkan dalam suatu konteks agar aplikatif.

Selama ini Pendidikan Agama di Indonesia mengikuti sistem yang berlaku di Barat sehingga Pendidikan Agama tidak masuk dalam konteks sektor publik. Pendidikan identitas yang disosialisasikan dalam sektor publik adalah Pendidikan Sejarah, eks-PSPB dan Pendididkan Kewarganegaraan. Ketiga pendidikan ini menekankan pada konsep nasionalisme sebagai penopang bagi eksistensi negara bangsa Indonesia. Saya melihat pendidikan identitas ini gagal menjalankan misinya karena nasionalisme sebagai produk peradaban Barat tidak pernah dimaksudkan sebagai sumber nilai. Seharusnya dalam pendidikan identitas itu diselipkan nilai-nilai agama, karena agama merupakan sumber nilai yang otoritatif. Memang Pendidikan Agama perlu dijabarkan dalam Paradigma Historis agar operasional, karena seperti contoh di atas, konsep keadilan adalah sesuatu yang abstrak dan perlu diterapkan atau dibandingkan dengan suatu konteks historis yang jelas.

Berdasarkan batasan permasalahan di atas maka dapat dirumuskan permasalahan penelitian sebagai berikut:

1. Apakah yang dimaksud dengan paradigma historis pendidikan agama?

2. Bagaimanakah wujud pendidikan agama berdasarkan paradigma historis itu? 
3. Bagaimanakah teologi sektor publik menurut agama Islam?

4. Bagaimanakah pendidikan identitas sektor publik berdasarkan paradigma historis?

5. Sejauhmanakah sampel buku Pendidikan Agama SMP dari kelas 1-3 sudah menerapkan paradigma historis?

6. Sejauhmanakah buku Pendidikan Agama di SMP itu mencerminkan pendidikan identitas sektor publik?

\section{TINJAUAN PUSTAKA}

Indonesia dapat dikatakan sebagai negara Islam, dalam arti mayoritas penduduknya beragama Islam, dan bahkan negara berpenduduk Muslim terbesar di dunia. Tetapi ironisnya, Indonesia merupakan salah satu negara terkorup di dunia. Hal ini menunjukkan kita sedang menderita krisis akut di era modern sekarang ini. Dalam situasi yang kalut ini kita seringkali menyalahkan pada peradaban Barat sebagai akar dari semua permasalahan ini. Kita hendaknya bersifat obyektif dengan menerima apa-apa yang baik dari Barat dan berusaha menawarkan alternatif bagi perbaikan keadaan yang sedang berlangsung.

Salah satu dampak negatif peradaban Barat adalah menyebarnya virus sekulerisme sebagai penyebab dari atheisme. Walaupun orang Barat masih mempercayai akan eksistensi Tuhan, 92\% di USA (BBC News, 2004: 1-3), tetapi mereka sudah tidak menjalankan ritus-ritus agama formal, sehingga mereka dikenal dengan penganut “deisme” (Nurcholish Madjid, 1995: 150-151).

Atheisme simbolik mungkin sulit menimpa umat Islam karena Al-Qur'an dan Hadits sudah mengatur ritual agama secara rinci, tetapi secara substansi kita mungkin sudah jumbuh dengan sikap atheis karena kita masih saja mengekor pada kemajuan 
peradaban Barat. Seharusnya kita kritis, bukan berarti anti, terhadap ideologi-ideologi produk Barat agar disesuaikan dengan situasi dan kondisi serta sejarah bangsa sendiri. Paradigma historis dimaksudkan menempatkan ideologi-ideologi produk Barat dan juga agama dalam konteks Indonesia dan selanjutnya menempatkan agama dalam dialektika dengan kemajuan ipteks agar menjadi agama reformatif (Saefur Rochmat, 2005: 269).

Wabah sekulerisme tidak dapat dihadapi sendiri oleh umat Islam, bukankah umat Kristen dan Yahudi secara bersama-sama telah gagal membendung laju sekulerisme. Sekulerisme harus dilawan melalui kerjasama semua agama, sehingga Pendidikan Agama dituntut tidak lagi bersifat eksklusif. Hal ini hanya mungkin dilakukan bila kita mengadopsi Paradigma Historis dan lalu kita dituntut untuk merumuskan Teologi Sektor Publik. Teologi Sektor Publik ini dimaksudkan untuk mereformasi pendidikan identitas yang bertumpu pada Pendidikan Sejarah, eksPSPB, dan Pendidikan Kewarganegaraan karena terlampau menekankan segi nasionalisme, padahal nasionalisme sebagai produk peradaban Barat tidak pernah dimaksudkan sebagai sumber nilai. Pendidikan Agama yang disusun dengan Paradigma Historis diharapkan mampu ditampilkan dalam sektor publik.

Kerangka teori tersebut disusun berdasarkan referensi dari berbagai sumber. Teologi Sektor Publik sebagai suatu bentuk teologi baru diambil dari pendapat Amos Funkenstein dalam bukunya Theology and the Scientific Imagination: from the Middle Ages to the Seventeenth Century dan tulisan M. Amin Abdullah (2005). Kedua buku itu menjelaskan bahwa Teologi tradisional menggunakan pendekatan klasik Filsafat Stoic yang mendasarkan diri pada prosedur logika sebagai pisau analisa. Pendekatan filsafat ini merupakan pengaruh Filsafat Skolastik Aristoteles, bukan pendirian Aristoteles dan Plato sendiri. Perhatian Skolastik Aristoteles lebih 
kepada definisi dan cenderung memilahkan sesuatu hitam-putih. Sedangkan menurut Aristoteles dan juga diikuti kelompok Burhani di dunia Muslim, kebenaran itu menuntut keselarasan antara konsep dan fenomena atau bersatunya pengetahuan dengan perbuatan (Verum et factum convertuntur).

Teologi Sektor Publik dalam Islam yang dirumuskan sebagai hasil dialektika Rukun Iman dan Rukun Islam dielaborasi dari pemikiran KH Abdurrahman Wahid (Gus Dur) dalam bukunya Prisma Pemikiran Gus Dur dan Menggerakkan Tradisi: Esai-Esai Pesantren. Keduanya diterbitkan oleh LKIS. Teologi Sektor Publik merupakan hasil reinterpretasi ajaran agama sebagaimana yang tertuang dalam AlQaur'an. Sebagaimana diuraikan dalam bukunya Tuhan Tidak Perlu Dibela, Gus Dur dengan elegan menafsirkan kembali ajaran agama untuk memenuhi kebutuhan kehidupan modern. Hasil dari dialektika agama dan ipteks modern dikenal dengan Agama Reformis (Saefur Rochmat, 2005). Saefur (2004) dalam buku Sejarah Islam Indonesia menawarkan paradigma Islam Historis didalam memaknai kembali AlQur’an, dimana Al-Qur’an dan perkembangan ipteks harus difilter dengan kondisi historis daerah yang menjadi sasaran dakwah.

Al-Qur'an sebagai teks terbuka memungkinkan adanya multitafsir berdasarkan konteks historis sasaran dakwah yang berbeda. Untuk dapat memahami suatu norma dalam Al-Qur'an secara kritis, kita perlu memahami pendekatan hermenetika yang diperkenalkan Jurgen Habermas. Kajian kritis terhadap karyanya dapat dipelajari dari John B. Thompson dalam Studies in the Theory of Ideology. Penafsiran kembali Al-Qur'an secara kritis dimaksudkan untuk mengatasi krisis akut dunia modern yang sedang dilanda wabah sekulerisme. Wabah ini hanya mungkin dihentikan oleh agama, bila agama-agama sudah mampu merumuskan Pendidikan 
Agama yang inklusif, sehingga mereka akan mampu merumuskan etika global secara meyakinkan (Hans Kung, 2002).

Teologi Sektor Publik adalah mutlak, karena setiap Muslim percaya kalau mereka berkewajiban menegakkan syariah (Islamic law). Memang ada berbagai penafsiran tentang syariah, dan yang ditawarkan disini adalah syariah yang bebas kepentingan politik karena penulis percaya kalau kebenaran Islam bersifat obyektif dan tidak memerlukan dukungan kekuatan politik. Memang dalam implementasi kebenaran Islam memerlukan suatu power tapi tidak harus bermakna politik. Yang sering dipahami secara salah kaprah adalah memahami syariah Islam identik dengan fiqih (Lies Marcoes-Natsir, 2004).

\section{HASIL DAN PEMBAHASAN}

\section{A. PARADIGMA HISTORIS PENDIDIKAN AGAMA}

Usaha untuk memerankan agama sebagai alternatif bagi peradaban modern masih belum berhasil, karena segi material dari peradaban modern masih sangat menggiurkan, teristimewa bagi generasi muda. Mereka mudah sekali terlibat dalam perkelahian antar pelajar, mabuk-mabukan, dan perasaan frustasi maupun teralienasi. Apapun agamanya kita ditantang untuk membangun Masyarakat Madani untuk menghilangkan citra agama sebagai sumber konflik, dengan cara menyusun sistem pendidikan agama maupun sistem pembinaan kehidupan antar umat beragama secara komprehensif. Upaya tersebut perlu segera diwujudkan untuk menyelamatkan generasi muda dari dampak negatif peradaban Barat, disamping berusaha menjadikan agama sebagai alternatif bagi peradaban Barat.

Paradigma historis pendidikan agama berpretensi mengembangkan pendidikan agama yang tidak bersifat konvensional melalui pendekatan teologi 
(model pemikiran deduktif) yang mementingkan pada truth claim masing-masing agama. Truth claim yang berbeda tidak perlu dirisaukan bila hanya terbatas kepada aspek ontologis-metafisis, namuan truth claim seringkali memasuki wilayah sosiopolitik yang praktis-empiris. ${ }^{1}$ Perbedaan truth claim bisa diatasi dengan pandangan Traditisionalis dalam Religious Studies yang dikenal dengan istilah aspek exoterism (aspek luar suatu agama) dan aspek esoterism (aspek dalam atau rasa). Exoterism menunjukkan bahwa dari sisi luar ada berbagai macam agama, namun dari sisi esoterism hanya ada satu spiritualitas (Tuhan), yang hanya dapat ditangkap dengan hati. $^{2}$ Dengan demikian kita harus mengganti konsep kebenaran tunggal dalam kehidupan beragama karena kebenaran mutlak hanyalah milik Tuhan; dan kita juga harus mengganti konsep kapling surga bagi golongannya sendiri dengan konsep surga untuk semua pemeluk agama. Memang kita harus tetap mempunyai fanatisme dalam beragama, yaitu meyakini jalan yang ditempuh adalah jalan yang terbaik dan mampu mengoptimalkan semua potensi pribadi yang dimilikinya.

Paradigma historis berpretensi menggabungkan pendekatan konvensional (model deduktif) dengan model induktif, sehingga agama tidak hanya mengajarkan doktrin-doktrin agama saja tetapi juga mengkaitkan dengan permasalahan dalam kehidupan sehari-hari (kontekstual), disamping tetap mengikuti semangat zaman (kesadaran historis). Dalam kasus Indonesia, perlu mengembangkan konsep Masyarakat Madani karena sesuai dengan pluralitas masyarakat Indonesia. Untuk itu perlu dikembangkan pendidikan agama yang tidak bersifat doktriner dan telah dikembangkan Trilogi Kerukunan Umat Beragama, yang kemudian disempurnakana dengan Dialog Antar Iman. Dalam kaitannya kesadaran historis, diadopsi dualisme

\footnotetext{
${ }^{1}$ Amin Abdullah. Op. Cit. Hal. 47.

${ }^{2}$ Hudson Smith. (1984). "Introduction to the Revised Edition”. Dalam Frithjof Schuon. The Transendent Unity of Religions. Wheaton: The Theosophical Publising House. Hal. xii-xiii.
} 
legalitas, yakni negara memberikan legitimasi kepada semua agama dan semua agama memberikan legitimasi kepada negara sehingga negara tidak boleh terlalu jauh mencampuri urusan agama seperti melakukan penilaian baik-buruk terhadap suatu agama.

\section{B. MODEL PARADIGMA HISTORIS PENDIDIKAN AGAMA}

Paradigma Historis Pendidikan Agama berusaha mengembangkan suatu model pendidikan agama yang mensintesakan agama dengan modernisasi, agar agama fungsional dalam kehidupan modern. Model ini berusaha menggabungkan pendekatan doktriner-normatif dengan pendekatan induktif-historis. Akan tetapi model ini merupakan antitesa baik terhadap pandangan konvensional pendidikan agama yang menekankan teologi per se maupun pandangan modern yang bertumpu pada ideologi. Keduanya merupakan dua sisi mata koin yang memiliki makna yang sama "membedakan kelompok kita dan kelompok mereka”, hanya teologi lebih menekankan pada 'truth claim', sedangkan modernisme lebih menekankan pada 'ideologi'. Walaupun modernisme berpretensi sebagai pembela humanisme, bahkan modernisme mendasarkan diri pada humanisme untuk menolak agama yang dianggapnya telah mensubordinasikan manusia pada kekuatan di luar dirinya. Modernisme mengaku sebagai pembela paham-paham seperti humanisme (karena saya berpikir maka saya ada), liberalisme (karena manusia pada dasarnya baik maka harus diberi kebebasan), atheisme (tidak percaya kepada Tuhan), dan sekulerisme (memisahkan yang sekuler dan religious). Akan tetapi modernisme tidak mengembangkan paham humanisme yang murni ketika ia membedakan manusia kedalam ideologi-ideologi yang mendorong perpecahan dan peperangan sesama 
manusia, karena pada dasarnya ideologi mengenal ”kelompok kita” dan ”kelompok mereka”. Kekerasan dan peperangan jelas-jelas mengingkari visi humanisme.

Paradigma historis berpretensi mengatasi kelemahan kedua pendekatan tersebut di atas memposisikan diri sebagai pembela visi humanisme yang sebenarnya dengan menghindarkan diri dari kekerasan dalam kehidupan sehari-hari. Pendekatan ini tidak membedakan manusia ke dalam ideologi yang saling bertentangan, meskipun tidak mengingkari adanya perbedaan dalam masyarakat, karena manusia disatukan oleh visi humanisme yang murni, sebagai suatu pemberian dari Tuhan. Karena itu, pendekatan ini mengakui eksistensi Tuhan, namun menghindari adanya truth claim sebagaimana yang ditekankan oleh pendekatan teologi, disamping mengadopsi perkembangan ipteks modern agar agama bisa mengatasi permasalahan pada era modern.

Model yang perlu dikembangkan berdasarkan pendekatan historis adalah Agama Reformis, dimana agama difungsikan sebagai motor penggerak perubahan, dengan menjadikan agama selalu bersentuhan dengan konsep-konsep modern, namun ia bersifat kritis terhadap pendekatan ideologis-revolusioner, sehingga ia mengembangkan pendekatan reformatif-evolusioner.

\section{TEOLOGI SEKTOR PUBLIK}

Teologi baru di sektor publik diperlukan agar pengalaman traumatik peradaban Barat yang telah melahirkan dua kali Perang Dunia, dua kali Perang Teluk, dan banyak revolusi yang menginjak-injak kemanusiaan tidak terulang lagi. Teologi baru ini setuju dengan gerakan sekulerisasi, yang memisahkan managemen sektor private dengan sektor publik, agar tercipta akuntabilitas dan transparansi dalam kedua sektor itu, disamping mencegah politisasi agama. 
Teologi baru ini juga sebagai koreksi terhadap gerakan sekulerisasi yang berdampak pada menyebarnya wabah sekulerisme; padahal keduanya sangat berbeda secara substansial. Sekulerisme, suatu ideologi yang memandang nilai terakhir kebenaran pada materi, jelas bertentangan dengan agama yang muara terakhirnya tauhid atau monotheisme, bahwa segala sesuatu berawal dan berakhir pada Allah. Sekulerisme itu muncul karena pemikiran agama tidak dimaksudkan juga menangani permasalahan kemanusiaan di dunia ini seperti korupsi.

Islam punya konsep yang dapat ditawarkan untuk mencegah sekulerisme pada sektor publik bila kita mau merevisi pemahaman kita pada fiqh konvensional yang dalam sejarah Islam telah diperankan dalam sektor publik. Fiqh konvensional harus rela melepaskan beberapa hak yang diklaim sebagai hak masyarakat, agar tidak melanggar sektor private, seperti yang dijabarkan dalam Rukun Iman. Dialektika Rukun Iman (sektor masyarakat) dengan Rukun Islam (sektor private) inilah yang akan melahirkan Rukun Sosial (sektor publik).

\section{PENDIDIKAN AGAMA SEKTOR PUBLIK}

Selama ini pendidikan identitas yang diamanatkan pada pendidikan sejarah, PSPB, dan PPKn gagal memenuhi misinya, karena pendidikan identitas dimaknai secara sempit sebagai nasionalisme. Ini suatu yang kontadiktif, karena pendidikan identitas mengimplikasikan adanya sosialisasi nilai-nilai, sedangkan nasionalisme yang diadopsi dari peradaban Barat sekuler itu tidak pernah dimaksudkan sebagai sumber nilai. Untuk itu, nasionalisme perlu suntikan dari agama, suatu yang memang memerankan diri sebagai sumber nilai. Atau, nasionalisme disampaikan dalam kerangka budaya lokal yang religious, mengingat budaya lokal memiliki fungsi sebagai sumber nilai. 
Hendaknya pendidikan agama juga diperankan sebagai pendidikan identitas, yaitu pendidikan yang mengarah pada pembentukan solidaritas sosial dan selanjutnya mendorong terbentuknya conscience collective (kesadaran sosial), sebagai wujud moralitas masyarakat, yang dengannya semua anggota masyarakat harus mengikatkan diri. Pendidikan agama dapat mengemban amanat ini bila pendidikan agama tidak disampaikan secara doktriner normatif an sich, tetapi dilengkapi dengan pendekatan induktif, yang mengkaji praktek kehidupan beragama di masyarakat secara obyektif, dengan mempertimbangkan situasi, kondisi, dan sejarah daerah tempat berlangsungnya kontekstualisasi ajaran normatif agama.

Pendidikan sejarah/PSPB/PPKn juga harus disampaikan dalam keserasian dengan budaya lokal. Selama ini ada gap antara pemerintah yang mengklaim sebagai vanguard nasionalisme-sentralistis yang sah dengan daerah berserta budaya lokalnya yang dianggap punya kecenderungan anti-sentralisasi. Mengingat nasionalisme tidak pernah berpretensi sebagai sumber nilai maka hendaknya ia dikemas dalam bingkai agama maupun budaya agar punya makna nilai. Lagipula, materi pendidikan identitas dalam skup nasional tentu saja sangat abstrak bagi siswa SD. Pendidikan identitas harus terkait dengan kesadaran ruang; semakin tinggi pendidikannya semakin luas pula ruang lingkup bahasannya.

\section{E. ANALISA BUKU PENDIDIKAN AGAMA SMP KELAS I, II, III}

Buku pendidikan agama yang dianalisa dalam penelitian ini merupakan buku pelajaran agama bagi siswa SMP kelas 1, 2, dan 3. Buku itu merupakan buku terbaru yang diterbitkan pada tahun 2007 dan disusun berdasarkan standar isi BSNP (Badan Standar Nasional Pendidikan). Buku yang dianalisa dalam penelitian ini berasal dari dua penerbit yang berbeda, Yudistira dan Erlangga, untuk mengetahui sejauhmana 
persamaan dan perbedaan materi maupun metoda dalam penyampaiannya yang disusun berdasarkan standar kompetensi yang telah ditentukan oleh BSNP. Standar Kompetensi yang ditentukan oleh BSNP dapat dipilah menjadi: Al-Qur’an, Akidah, Akhlak, Fiqih, dan Tarikh dan Kebudayaan Islam. Standar Kompetensi dijabarkan ke dalam Kompetensi Dasar yang harus diajarkan kepada siswa pada setiap semester. Walaupun Standar Kompetensi itu sama, namun Kompetensi Dasar pada tiap semester itu berbeda dan disusun berdasarkan tingkat kesulitan yang sudah sesuai dengan tingkat perkembangan psikologi maupun intelektual siswa.

Pada dasarnya materi yang disampaikan oleh penulis adalah sama, baik dari penerbit Yudistira maupun Erlangga karena disusun berdasarkan Standar Kompetensi dan Kompetensi Dasar yang sudah ditentukan oleh BNSP. Materi yang diberikan maupun pembagian materi ke dalam bab oleh kedua penerbit agak berbeda, namun tidak mengurangi nilai dari Standar Kompetensi maupun Kompetensi Dasar yang telah ditentukan oleh BSNP.

Pendekatan historis dan kontekstual baik dapat digunakan sebagai metoda dalam penyampaian pendidikan agama agar doktrin agama itu fungsional dalam kehidupan modern. Adakalanya kita tidak dapat menggunakan kedua pendekatan secara bersama-sama dalam menjelaskan suatu materi pelajaran, namun salah satu dari pendekatan itu secara sendiri-sendiri dapat digunakan untuk menjelaskan materi pelajaran agama. Bahkan, baik pendekatan historis maupun kontekstual dapat digunakan pada Standar Kompetensi yang kelihatannya ekslusif dalam pendidikan agama, yaitu Al-Qur’an, Akidah, Akhlak, dan Fiqih. Satu-satunya Standar Kompetensi terkait erat dengan pendekatan historis dan kontestual adalah Tarikh dan Kebudayaan Islam. 


\section{KESIMPULAN}

Paradigma historis pendidikan agama dimaksudkan agar agama itu fungsional dalam kehidupan modern. Untuk itu, agama harus ikut menangani permasalahan pada era modern ini, mengarahkan perkembangan ilmu modern, dan mengadopsi serta mengembangkan ide-ide dan konsep-konsep modern. Umat Islam perlu akrab dengan permasalahan kemodernan seperti negara bangsa, nasionalism, dan demokrasi.

Model pendidikan agama berdasarkan paradigma historis itu menggabungkan pendekatan konvensional yang bersifat dogmatis-normatif, pendekatan historis, dan pendekatan kontekstual. Model yang perlu dikembangkan berdasarkan pendekatan historis adalah Agama Reformis, dimana agama difungsikan sebagai motor penggerak perubahan, dengan menjadikan agama selalu bersentuhan dengan konsepkonsep modern, namun ia bersifat kritis terhadap pendekatan ideologis-revolusioner, sehingga ia mengembangkan pendekatan reformatif-evolusioner.

Teologi Baru Sektor Publik diperlukan agar pengalaman traumatik peradaban Barat yang telah melahirkan dua kali Perang Dunia, dua kali Perang Teluk, dan banyak revolusi yang menginjak-injak kemanusiaan tidak terulang lagi. Teologi baru ini berpretensi menggabungkan "teologi" dengan perkembangan "ilmu pengetahuan, teknologi, dan filsafat”. Teologi Sektor Publik setuju dengan gerakan sekulerisasi, yang memisahkan managemen sektor private dengan sektor publik, agar tercipta akuntabilitas dan transparansi dalam kedua sektor itu, disamping mencegah politisasi agama. Teologi Sektor Publik mungkin kita rumuskan bila kita mau merevisi pemahaman kita pada fiqh konvensional yang dalam sejarah Islam telah diperankan dalam sektor publik. Fiqh konvensional harus rela melepaskan beberapa hak yang diklaim sebagai hak masyarakat, agar tidak melanggar sektor private, seperti yang 
dijabarkan dalam Rukun Iman. Dialektika Rukun Iman (sektor masyarakat) dengan Rukun Islam (sektor individu ) melahirkan Rukun Sosial (sektor publik).

Selama ini pendidikan identitas yang diamanatkan pada pendidikan sejarah, PSPB, dan PPKn gagal memenuhi misinya, karena pendidikan identitas dimaknai secara sempit sebagai nasionalisme. Padahal nasionalisme yang diadopsi dari peradaban Barat sekuler itu tidak pernah dimaksudkan sebagai sumber nilai. Untuk itu, nasionalisme perlu suntikan dari agama, suatu yang memang memerankan diri sebagai sumber nilai. Atau, nasionalisme disampaikan dalam kerangka budaya lokal yang religious, mengingat budaya lokal memiliki fungsi sebagai sumber nilai. Lagipula, materi pendidikan identitas dalam skup nasional tentu saja sangat abstrak bagi siswa SD. Pendidikan identitas harus terkait dengan kesadaran ruang; semakin tinggi pendidikannya semakin luas pula ruang lingkup bahasannya.

Buku pendidikan agama yang dianalisa dalam penelitian ini secara umum masih menggunakan pendekatan konvensional. Pendekatan historis dan kontekstual baik dapat digunakan sebagai metoda dalam penyampaian pendidikan agama agar doktrin agama itu fungsional dalam kehidupan modern. Adakalanya kita tidak dapat menggunakan kedua pendekatan secara bersama-sama dalam menjelaskan suatu materi pelajaran, namun salah satu dari pendekatan itu secara sendiri-sendiri dapat digunakan untuk menjelaskan materi pelajaran agama. Bahkan, baik pendekatan historis maupun kontekstual dapat digunakan pada Standar Kompetensi yang kelihatannya ekslusif dalam pendidikan agama, yaitu Al-Qur’an, Akidah, Akhlak, dan Fiqih. Satu-satunya Standar Kompetensi terkait erat dengan pendekatan historis dan kontestual adalah Tarikh dan Kebudayaan Islam. 


\section{DAFTAR PUSTAKA}

Abdullah, M. Amin, 2005, "Democracy and Authoritarianism in Islamic Text: The Implication and the Consequences of having Bayani type of Islamic Epistemology in the Political Arena”, in ICIP Journal, vol. 2, no. 2.

2001, "Pengajaran Kalam dan Teologi di Era Kemajemukan: Sebuah Tinjauan Materi dan Metode Pendidikan Agama”, dalam Tashwirul Afkar, No. 11.

Abdullah, Taufik, 2004, “Di sekitar Gugatan terhadap Pelajaran dan Buku Sejarah”, dalam Historia No. 9, Vol. V, p. 33.

Al-Hilalli, Muhammad Taqi-ud-Din dan Muhammad Muhsin Khan, 1996, Interpretation of the Meaning of the Noble Qur'an, Riyadh: Darussalam.

Attas, Syed Muhammad Naquib al-, (1993), Islam and Secularism. Kuala Lumpur: ISTAC.

Barnet, Tony, 1995, Sociology and Development, London: Routledge.

BBC News, 2004, “UK among most secular nations”, dalam http://news.bbc.co.uk/1/hi/programmes/wtwtgod/3518375.stm. 2004, pp. 1-3 $<$ Diakses 2005/06/20>.

Bellah, Robert N, 1973, Durkheim on Morality and Society, Chicago, The University of Chicago Press.

Carr, E.H., 1984, Apakah Sejarah? A.b. Rahman Haji Ismail. Kuala Lumpur. Dewan Bahasa dan pustaka.

Dabashi, Hamid, 1993, Theology of Discontent: The Ideological Foundation of the Islamic Revolution in Iran. New York: New York University Press.

Davies, Paul, 2001. Membaca Pikiran Tuhan: Dasar-Dasar Ilmiah dalam Dunia Yang Rasional, Yogyakarta: LKIS.

Fadjar, Abdullah, 1991, Peradaban dan Pendidikan Islam. Jakarta: Rajawali Press.

FMIPA, 2003, “Geografi, Geografi Lingkungan, dan Proses Hidrologis”, Online http://www.malang.ac.id/e-learning/FMIPA/Budi\%20Handoyo/geografi.htm $<$ Diakses 15-10-2005>.

Funkenstein, Amos, 1986, Theology and the Scientific Imagination: from the Middle Ages to the Seventeenth Century, Princeton: Princeton University Press.

Gamble, Andrew, 1988, An Introduction to Modern Social and Political Thought. Hongkong. Macmillan Education Ltd.

Gie, The Liang, 1998, Philosophy as an Element of Human Existence. Yogyakarta: PUBIB.

Goldstone, Jack A. ed., 1986, Revolutions: Theorical, Comparative, and Historical Studies. USA, Hourcourt: Brace Javanovich Publisher.

Gottschalk, Louis, 1986, Mengerti Sejarah. A.b. Nugroho Notosusanto. Jakarta: UI Press. 
Harahap, Nasruddin dkk. (Eds.), 1992, Dakwah Pembangunan. Yogyakarta: DPD Golkar Tk. I DIY.

Hasbullah, 1999, Sejarah Pendidikan Islam di Indonesia: Lintasan Sejarah dan Perkembangan. Jakarta: LSIK dan Rajawali Press.

Hatto, A.T., 1972, “The Semantics of 'Revolution’”, dalam P.J. Vatikiotis ed., Revolution in the Middle East and Other Case Studies. London: Allen and Unwin Ltd.

Hidayat, Komaruddin dan Ahmad Gaus AF eds., 1998, Passing Over: Melintas Batas Agama, Jakarta: Gramedia dan Paramadina.

Juergensmeyer, Mark, 1993, The New Cold War? Nationalism Confronts the Secula State. California: University of California Press.

Kartodirdjo, Sartono, 1993, Pendekatan Ilmu Sosial dalam Metodologi Sejarah. Jakarta: Gramedia.

Kohn, Hans, 1935, “Messianism”, dalam Edwin R.A. Seligman, eds. Encyclopedia of the Social Sciences. Vol.9. New York: The Macmillan Company.

Komaruddin Hidayat, 1995, “Kata Pengantar”, dalam Nurcholish Madjid Islam Agama Peradaban: Membangun Makna dan Relevansi Doktrin Islam dalam Sejarah, Jakarta: Paramadina.

Kung, Hans, 2002, Etika Ekonomi-Politik Global, A.b. Ali Noer Zaman, Yogyakarta: CV Qalam.

Kuntowijoyo, 2002, "Periodisasi Sejarah Kesadaran Keagamaan Umat Islam Indonesia: Mitos, Ideologi, dan Ilmu”, dalam Inovasi Vol. XI No. 2. 1999, Budaya dan Masyarakat. Yogyakarta: Tiara Wacana.

Laksono, P.M., 1985, Tradisi dalam Struktur Masyarakat Jawa Kerajaan dan Pedesaan. Yogyakarta: Gadjah Mada University Press.

Lambon, A.K.S., 1956, Quis Custodiet Custodes: Some Reflections on The Persian Theory of Government. Studies Islamica, Vol.5.

Lawrence, Bruce B., 1989, The Fundamentalist Revolt against the Modern Age. New York: Harper \& Row.

Maarif, Ahmad Syafii, 1994, Filsafat Sejarah. Yogyakarta: Jurusan Pendidikan Sejarah.

Madjid, Nurcholish, 1998, “Dialog Agama-agama dalam Perspektif Universalisme alIslam”, dalam Hidayat, Komaruddin dan Ahmad Gaus AF eds. Passing Over: Melintas Batas Agama, Jakarta: Gramedia.

1995, Islam Agama Peradaban: Membangun Makna dan Relevansi Doktrin Islam dalam Sejarah, Jakarta: Paramadina. 
Monsma, Stephen V., 1996, Religious Nonprofit Organizations and Public Money: When Sacred and Secular Mix, Maryland: Rowman \& Littlefield Publishers, Inc..

Mukti Ali, A. 1971. Etika Agama dalam Pembentukan Kepribadian Nasional. Dalam A. Mukti Ali Etika Agama dalam Pembentukan Kepribadian Nasional dan Pemberantasan Kemiskinan dari Segi Agama Islam. Yogyakarta: Nida.

Mulkhan, Abdul Munir, 2001, “Humanisasi Pendidikan Islam”, dalam Tashwirul Afkar, No. 11.

Mustaqim. 1999. Pemikiran tentang Pendidikan Akhlak menurut Imam Ghazali. Dalam Ruswan Thoyib dan Darmuin (Peny.) Pemikiran Pendidikan Islam: Kajian Tokoh Klasik dan Kontemporer. Yogyakarta: Fakultas Tarbiyah IAIN Walisongo \& Pustaka Pelajar.

Muttaqin, Ahzab. 2002. Pendidikan Terpadu. Risalah Jum'at. Edisi 19/XI 19 Juli 2002.

Muzadi, A. Hasyim, 2005, “Busung Lapar dan Konstruksi Keimanan”, dalam Republika $19 \quad$ June 2005 http://groups.yahoo.com/group/kedungcinta/message/2165, <Accessed 2005/07/12>.

Nasikun (1991). Sistem Sosial Indonesia. Jakarta: Rajawali Press.

Nasr, Seyyed Hossein (1985). Ideals and Realities of Islam. London: Allen and Unwin.

Pardjono. 2002. Upaya Meningkatkan Kualitas Pendidikan Melalui Pendidikan Kecakapan Hidup (Life Skills). WUNY. Edisi Mei 2002.

Pickering, W.S.F. ed.(1975). Durkheim on Religion. London and Boston: Routledge \& Kegan Paul.

Rochmat, Saefur, 2006, “Abdurrahman Wahid on Reformulating the Theology of Islamic Democracy to Counter Secularism in Modern Era”, Ritsumeikan International Affairs, Vol. 6.

2006, “Korupsi dan Perlunya Teologi di Sektor Publik, Millah Jurnal Magister Studi Islam UII, vol. v No. 2.

2006, “MUI dalam Kasus Ahmadiyah: Dilihat dari Struktur Politik Orde Baru”, Inovasi Vol. 18, No. 7. Online http://ppi-jepang.org.

, 2005, “Kebangkitan Agama di Era Modern?”, dalam Inovasi, Tahun 7, vol 4, Online http://io.ppi-jepang.org/article.php?edition=4, <Diakses 2005/09/03>.

2005, “Agama Reformis: Dialektika Islam dan Modernisasi”, Hermeneia Jurnal Pasca IAIN Suka Vol. 4 No. 2.

2005, “Aspek Immaterial dalam Modernisasi, Inovasi Vol. 17, No. 3. Online http://ppi-jepang.org.

2005, “Kebangkitan Agama di Era modern?”, Inovasi Vol. 17, No. 5. Online http://ppi-jepang.org. 
2005, "Pendidikan Kecakapan Hidup dalam Bingkai Moral sebagai Strategi Broad Based Education”, Cakrawala Pendidikan Vol. 24, No. 1

2004, “Reformasi Dilihat dari Jepang”, Inovasi Vol. 16, No. 1. Online http://ppi-jepang.org.

2004, Sejarah Nasional Indonesia: Kontinyuitas Tradisi dan Modernisasi, Yogyakarta: BPFSS.

2004, "Tradisi dalam Pembentukan Identitas Bangsa Indonesia di Era Modern”, Cakrawala Pendidikan Vol. 233, No. 1.

2004, Sejarah Islam Indonesia: Kontinyuitas Tradisi dan Modernisasi, Yogyakarta: BPFSS.

2003, "Dialektika Pemikiran Keagamaan Muhammadiyah: Kontinyuitas Tradisi dengan Modernisasi”, Humanika Jurnal MKU, Vol. 3, No. 1.

2003, "Masyarakat Madani: Dialog Islam dan Modernitas di Indonesia”, Jurnal Pendidikan dan Kebudayaan Balitbang Depdiknas, Vol. 9, No. 41.

2002, "Reformasi Pendidikan Agama di Era Modern untuk Mewujudkan Masyarakat Madani”, Cakrawala Pendidikan Vol. 21, No. 3.

2002, “Studi Islam di Indonesia Era Millenium Ketiga”, Millah Jurnal Magister Studi Islam UII.

2002, “Dinamika Pondok Pesantren Gontor dalam Modernisasi”, JP Humaniora Lemlit UNY, Vol. 7, No. 2.

, 2002, "Potret Buram Pendidikan Indonesia”, Pewara, edisi khusus Mei 2002.

Roy, Oliver. (1994). The Failure of Political Islam. London: I.B Tauris \& Co Ltd.

1998, Fundamentalist without a common cause. The Guardian Weekly. October.

Shah, A.B., 1986, Metodologi Ilmu Pengetahuan. A.b. Hasan Basari. Jakarta: Yayasan Obor Indonesia.

Suhelmi, Ahmad, 2001, Dari Kanan Islam hingga Kiri Islam: Biografi dan Pemikiran Politik S.M. Kartosuwiryo, M. Natsir, M. Amien Rais, H.M. Ch. Ibrahim, M. Hatta, Abdurrahman Wahid, H.M. Misbach, Tan Malaka, Ali Syariati, Hassan Hanafi. Jakarta: Darul Falah.

Sumartana, 2005, “Kepekaan Teologi pada Tanda Zaman”, dalam http://www.tokohindonesia.co.id/ensiklopedi/s/sumartanath/sumartana_th2.shtml, <Diakses 2005/03/22>.

Tehrani, Faisal, 2002, “Nasionalisme dan Nepotisme Sama?”, Suara Anum.com, Online http://www.freewebs.com/suaraanum/1202a20.htm <Diakses 15-102005>.

Vatikiotis, P.J. ed., 1972, Revolution in the Middle East and Other Case Studies. London: George Allen and Unwin Ltd. 
Wahid, Abdurrahman, 2004, “Konsep-Konsep Keadilan”, dalam http://media.isnet.org/islam/Paramadina/Konteks/Keadilan.html, <Diakses 2004/09/22>.

, 2001, Menggerakkan Tradisi. Yogyakarta: LkiS.

, 2000, Tuhan Tidak Perlu Dibela. Yogyakarta: LkiS.

,1999, Prisma Pemikiran Gus Dur. Yogyakarta: LkiS.

Zada, Khamami, 2001, "Membebaskan Pendidikan Islam: dari Eksklusivisme menuju Inklusivisme dan Pluralisme”, dalam Tashwirul Afkar, No. 11, hal. 3.

Zainul, Asmawi, 2004, “Penerapan Asesmen Alternatif dalam Pembelajaran Sejarah”, Historia, No. 9, Vol. V. 